\title{
INCLUDING DEVELOPMENT TOPICS IN A CULTURAL HERITAGE MANAGEMENT PLAN: MERCURY HERITAGE IN IDRIJA
}

Janez Nared, Bojan Erhartič, Nika Razpotnik Visković

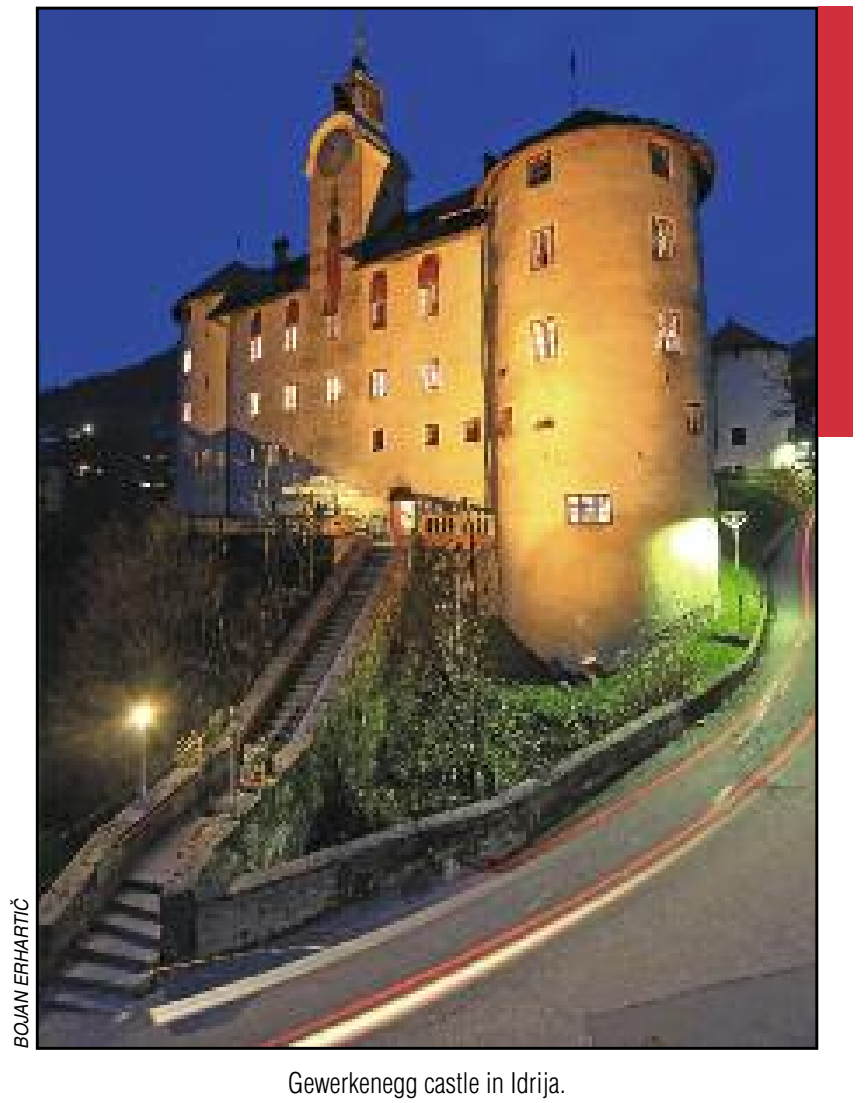




\title{
Including development topics in a cultural heritage management plan: Mercury heritage in Idrija
}

DOI: $10.3986 /$ AGS53404

UDC: 913:719(497.4Idrija)

COBISS: 1.01

\begin{abstract}
Mercury heritage in Idrija has been included on the UNESCO World Heritage List together with the Spanish town of Almadén. Idrija's rich cultural heritage thus became an important development factor that should be appropriately included in development documents, while preserving the integrity and authenticity of heritage, and taking into account its development role. This article presents the key findings of a participatory process whose goal is to form a cultural heritage management plan that will ensure that heritage becomes an important driver of municipal development. It highlights the need for comprehensive planning that includes all stakeholders, transcends divisions between sectors, and contributes to the harmonious and successful development of the area.
\end{abstract}

KEYWORDS: geography, regional development, regional management, cultural heritage, management plan, UNESCO, participatory process

\section{ADDRESSES:}

Janez Nared, Ph. D.

Anton Melik Geographical Institute

Research Centre of the Slovenian Academy of Sciences and Arts

Gosposka ulica 13, SI - 1000 Ljubljana, Slovenija

E-mail: janez.nared@zrc-sazu.si

Bojan Erhartič, Ph. D.

Anton Melik Geographical Institute

Research Centre of the Slovenian Academy of Sciences and Arts

Gosposka ulica 13, SI - 1000 Ljubljana, Slovenija

E-mail: bojaner@zrc-sazu.si

Nika Razpotnik Visković, Ph. D.

Anton Melik Geographical Institute

Research Centre of the Slovenian Academy of Sciences and Arts

Gosposka ulica 13, SI - 1000 Ljubljana, Slovenija

E-mail: nika.razpotnik@zrc-sazu.si

\section{Contents}

1 Introduction 395

2 Methods 395

3 UNESCO protection and development guidelines

$4 \quad$ Premises for preparing a management plan for mercury heritage in Idrija $\quad 396$

5 Conclusion 401

6 Acknowledgement 401

7 References 401 


\section{Introduction}

In line with UNESCO requirements (cf. Convention ... 1972 and Operational Guidelines ... 2012), cultural heritage that has been included on the world heritage list must have a suitable management plan that comprehensively defines the goals and measures for protecting, preserving, using, and developing protected monuments and areas. In this regard, one cannot ignore the spatial, economic, and social context of cultural heritage, which is why management plans must also ensure the goals and measures relevant to the development of entire area and community in addition to providing protection (Ringbeck 2008). Management plans must be closely connected with regional planning and development documents, especially if they seek to follow sustainable development, which has been at the center of international attention ever since the 1972 adoption of the Convention on the Protection of World Cultural and Natural Heritage (Operational Guidelines ... 2012).

Alongside ensuring environmental and cultural sustainability, cultural heritage can be used in various ways that can contribute to quality of life in individual communities; here it must be ensured that measures do not reduce the exceptional universal values of a specific protected monument (cf. Šmid Hribar and Ledinek Lozej 2013; Blešić et al. 2013). It does not suffice for an individual cultural heritage site to be protected (i.e., prevented from deteriorating); it is vital that this protection be complemented by components of education, identification, tourism, and development.

The economic potential of cultural heritage can be reflected in increased tourism flows and resulting multiplier effects. In addition, great potentials can also be found in marketing the entire region or brandscape. In this regard, the burdens (e.g., the number of visitors and increased traffic) should not exceed the carrying capacities or threaten the authenticity of the area or monument (Ringbeck 2008).

Cultural values are an important component of regional development, and their protection and development must be closely connected with planning and developing the entire region. According to the recommendations set out in the Convention (1972), heritage should be included in community life and this article therefore uses the example of mercury heritage in Idrija to draw attention to some of the opportunities that heritage offers to the region's development.

\section{Methods}

This article combines findings in spatial and development planning with the basic premises and guidelines of preserving cultural heritage. An overview of relevant findings in individual subject areas are improved by empirical findings obtained through a long-term development dialog with the residents of the area studied (i.e., Idrija). Cooperation with the Municipality of Idrija began in 2007 with the projects DIAMONT (cf. Razpotnik Visković, Nared and Urbanc 2008; Razpotnik Visković, Urbanc and Nared 2009) and CAPACities (Nared and Perko 2010; Nared et al. 2011; Urbanc, Nared and Bole 2012). In 2011, we launched a new series of meetings for developing a management plan for mercury heritage in Idrija. The issues discussed at the meetings included protection and development of this area, development starting points, relations among stakeholders, infrastructure, and the condition of individual monuments.

In developing the management plan, we proceeded from the fact that promotion of a participatory process is a key factor in ensuring sustainable development. It can reconcile differences in individual views, provide solutions acceptable to all social groups, prevent opposing competition, ensure the participation of local players, and enhance their creativity and profile. In addition, it makes it possible to communicate various interests and take them into account when making decisions and implementing activities. It includes the local know-how required to effectively carry out any activities within a specific local environment, and improves and enriches them using an interactive learning process. The participatory process contributes to better knowledge of the region, which is key in setting goals. The role of participatory planning is exceptionally important because the local culture, geographic conditions, economic condition, management methods, and mutual cooperation depend on specific local conditions that significantly influence the planners' decisions. With this it increases quality, legitimacy, the sense of community, and the support of residents in planning, which is a precondition for successfully implementing the planned activities (Zumaglini et al. 2008).

Regional players can be included in the planning process in various ways. We used workshops, interviews, and meetings with representatives of various institutions to develop the management plan. 


\section{UNESCO protection and development guidelines}

The protection and preservation of world heritage is the responsibility of the manager and must be congruent with the UNESCO guidelines in order to preserve the outstanding universal value, including the integrity and authenticity of a given region. A world heritage manager must also provide a suitable legal, institutional, and administrative basis for preserving heritage.

Effective management depends strongly on the type, characteristics, and needs of the world heritage site. The purpose of the management plan is to provide successful world heritage protection for the present and future generations. It is vital that the plan include local practices and regional planning concepts already in place.

The general guidelines for effective management and a management plan can be summarized in three concepts (Operational Guidelines ... 2012):

- Basic understanding of the world heritage site by all interested parties; cooperation between partners and stakeholders;

- Clear system of planning, implementing, and monitoring the condition of the world heritage site, evaluation, and feedback; effective monitoring of changes and proposed actions;

- Securing necessary funds.

The International Council on Monuments and Sites (ICOMOS), a nongovernmental UNESCO advisory body, is in charge of preserving cultural monuments and sites. Its basic task is to evaluate and prepare information regarding cultural and mixed/integral world heritage, provide advice for preserving and renovating monuments, and monitor the condition of cultural world heritage. The guidelines for preserving heritage are set out in a number of conventions and charters. The most important ones concerning Idrija's heritage include (Doktrina 12003 ) the Athens Charter for the Restoration of Historic Monuments (1931), the Venice Charter for the Conservation and Restoration of Monuments and Sites (1964), the International Charter for the Conservation of Historic Towns and Urban Areas (1987), the Charter on the Principles for the Analysis, Conservation, and Structural Restoration of Architectural Heritage (2003), and the Convention for the Safeguarding of Intangible Cultural Heritage (2003).

\section{Premises for preparing a management plan for mercury heritage in Idrija}

In summer 2012, mercury heritage in Idrija and Almadén was included on the UNESCO World Heritage List. Through this, the two sites were ascribed a universal value and at the same time they were given the important task of preserving their heritage and tradition. Idrija's entire old town is under UNESCO protection, and the city horizons are defined as its area of influence. Other protected sites include the smelting plant, the water-driven pump (Sln. kamšt), the headrace ( $r a k e$ ), and the Idrijca, Kanomlja, Belca, and Putrih logging sluices (klavže; Heritage ... 2012). A management plan must be prepared for these sites to establish a system of cultural heritage protection that will enable development at the same time. Development in particular is an especially demanding task because there is no uniform recipe available and all activities must be entirely subordinated to protecting extremely unique technical heritage.

The following factors key for developing the area and for the cultural heritage management method can be highlighted when preparing a management plan:

1. Due to its shared candidacy with Almadén, Idrija can increase its international profile but, on the other hand, this also entails difficult coordination between both sites;

2. The fact that Idrija is permeated with its mining tradition - which is reflected in numerous buildings, and rich technical and intangible heritage - dictated a broad definition of the area, which is why management is demanding and expensive;

3. Several institutions intended for preserving cultural heritage are active in the municipality, in which their operation to date will have to be harmonized and improved in order to achieve better organization and a uniform presentation in promotion and marketing. This can change the operational patterns in place, to which special attention must be dedicated in developing the management plan; 


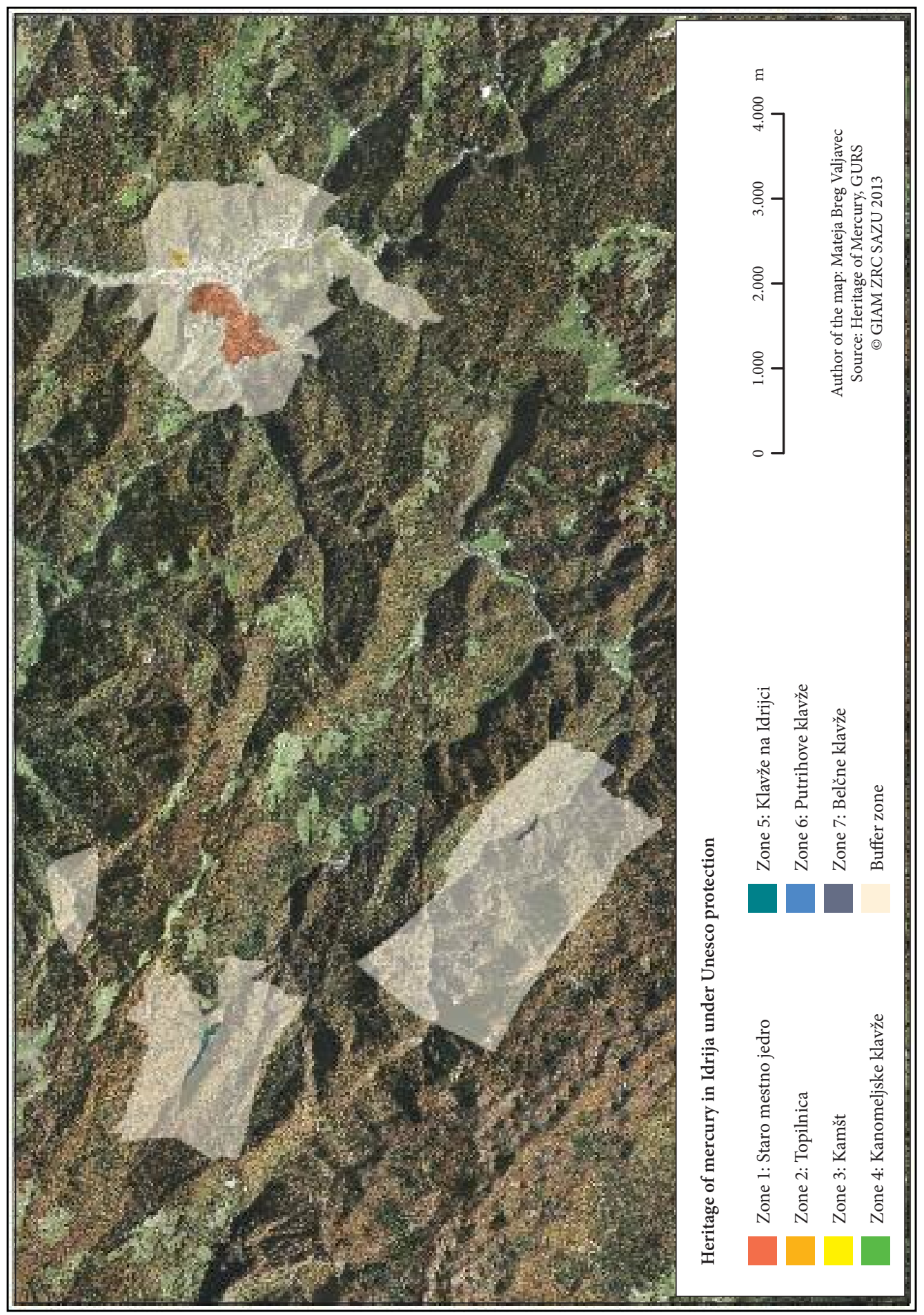




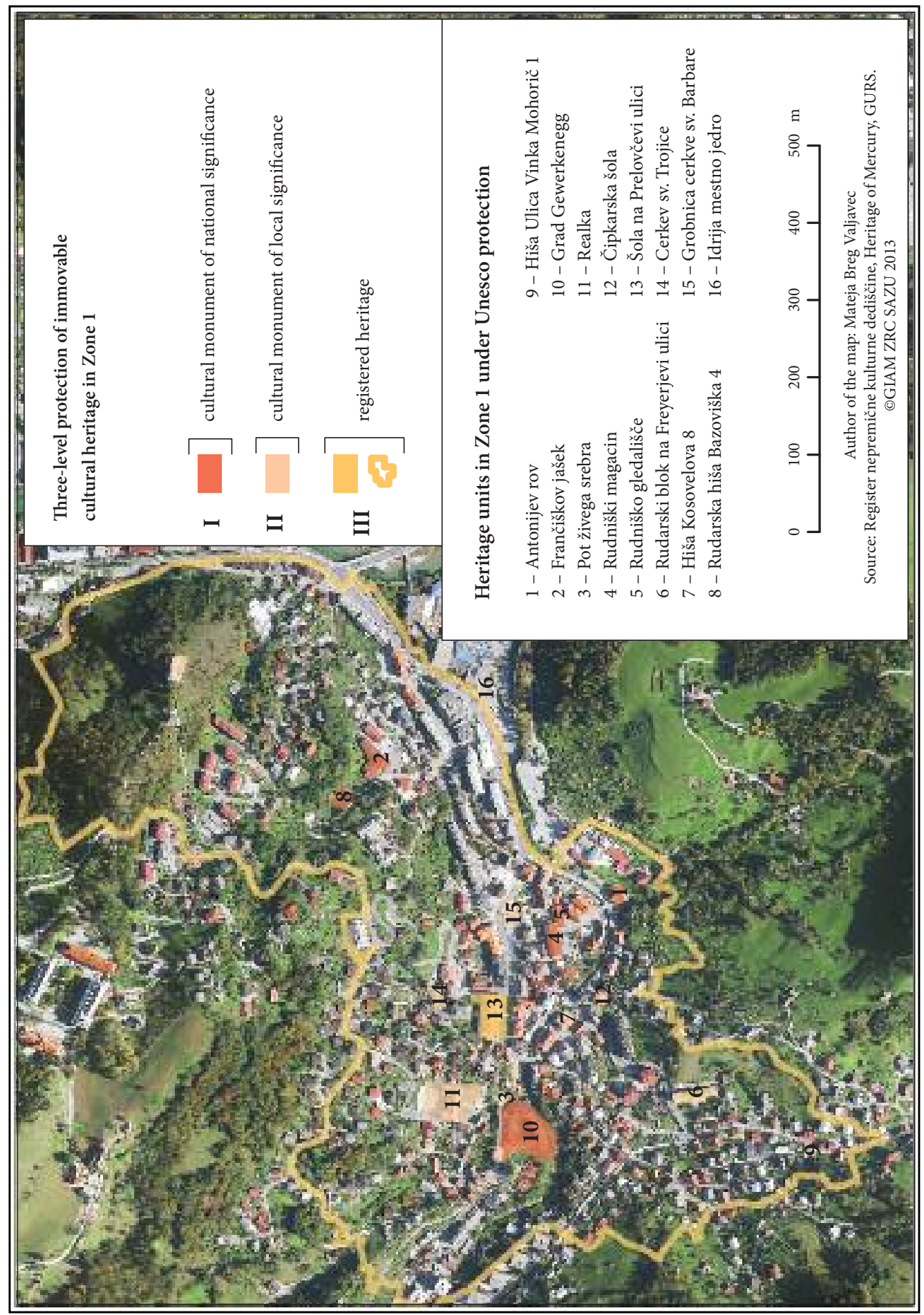


4. The key factor in developing a successful management plan is its flexibility and ability to include new stakeholders and ideas. The current cultural heritage managers have primacy in presenting heritage, but they must not threaten or obstruct new promotional forms and marketing approaches. It is vital that new approaches be in line with the values presented by the cultural heritage and that they ensure the preservation of its integrity and authenticity;

5. All of the owners of structures that the government has recognized as important monuments in the past should be encouraged to participate in the effective preservation and development of cultural heritage. This especially applies to privately owned structures because in this case a lack of inclusion and personal interest may result in monument deterioration;

6. An important challenge is also the government's relationship towards technical heritage in Idrija. The Idrija mercury mine is currently being liquidated, which threatens the key role it played in preserving the mining tradition, especially because its liquidation is also creating insecurity regarding the ownership of the protected mining structures;

7. In addition to harmonizing the relations between the current cultural heritage managers, the management plan will also have to include the entire city community in order to finalize the guidelines for future development;

This specific case of cultural heritage is special because it connects sites in Slovenia and Spain, and at the same time the Slovenian area studied is divided into seven zones. From the viewpoint of development, Zone 1 (i.e., Idrija's old town) is especially important. It includes several important monuments: Gewerkenegg Castle, the Anthony Shaft, the Magazin building (an old miners' granary and warehouse), the movie theater, two school buildings, the Francis Shaft, the miner's house, and Holy Trinity Church. In addition, it is also an area with combined administrative, economic, and housing activities. Therefore, in addition to protection it is vital to provide development opportunities such that cultural heritage will be an advantage and not an obstacle. This can be achieved through comprehensive revitalization of the city core, which takes into account the needs of the residents, economy, and visitors, while enriching and improving the heritage.

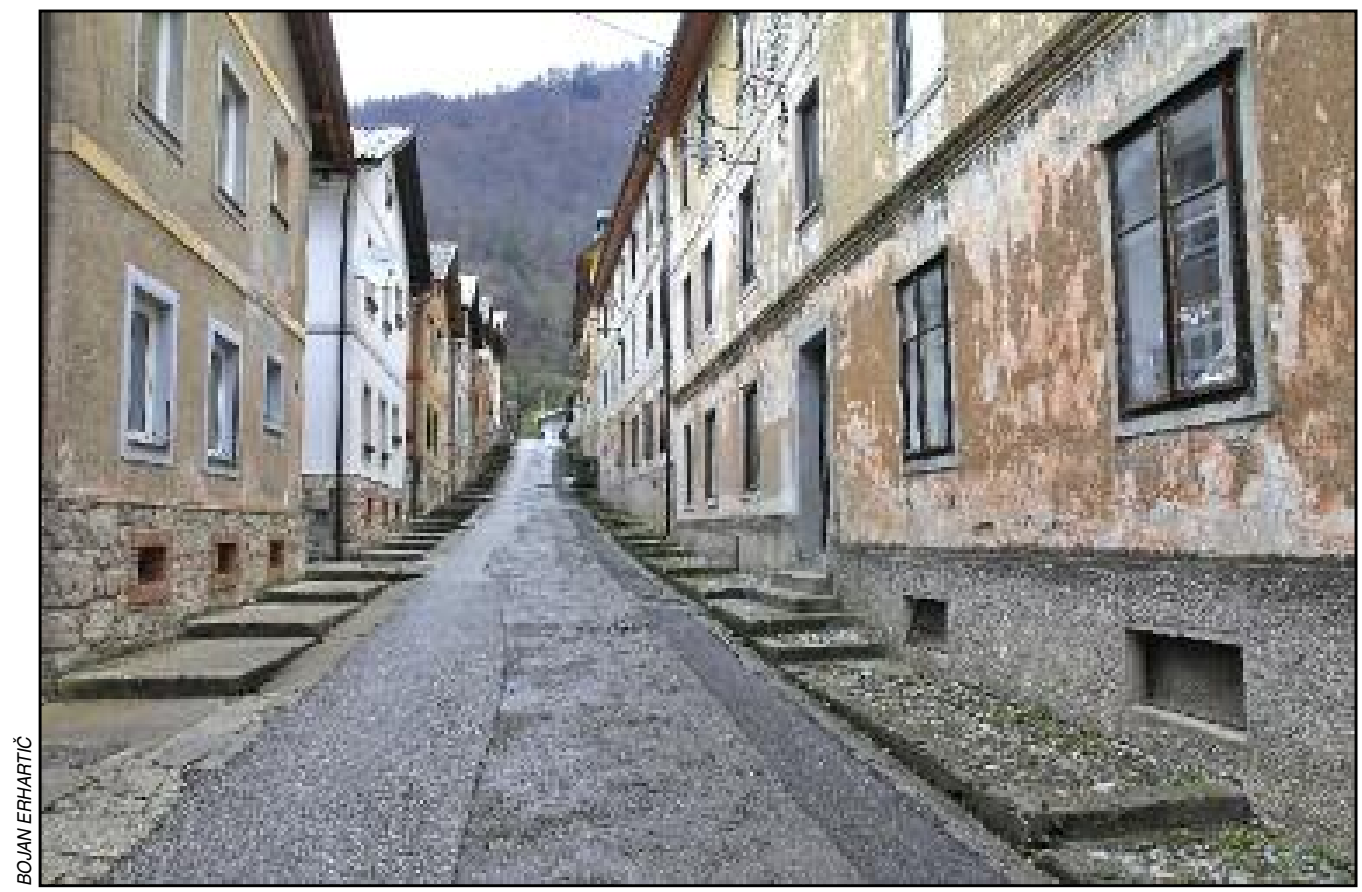

Figure 3: Miners' houses and apartment blocks from the end of the nineteenth century are an important part of world heritage. 
Revitalizing historic city centers is a response to resolving the problem of their demographic, economic, and cultural decline (Ferlež 2007). The reestablishment of a dynamic living environment within the city center by reviving its functions demands an interdisciplinary approach in order to purposefully introduce new economic, legal, social, construction, and environmental conditions to functionally revive the area (Reurbanisation ... 2005). The inclusion of mercury heritage in Idrija and Almadén on the UNESCO World Heritage List is an important basis, but not the only one, for revitalizing Idrija's historic center. The success of revitalization depends largely on educating, informing, and directly including all interested stakeholders in the area studied in the decision-making processes. In the case of Idrija, one must highlight the strong engagement of young people, who have realized that they do not receive sufficient attention from the municipal authorities (Straus et al. 2011), and have therefore conducted their own analysis of their situation in Idrija and subsequently also prepared a strategy with concrete proposals for reviving activities for young people in the area.

The revitalization of city centers is more successful when they are exposed to the " urban breeze, « whose diversity encourages locals and visitors to help shape the urban community and present proposals for improving the quality of life in the area (Lapuh 2012). Due to the international importance of its mercury mine, Idrija has been exposed to this urban breeze for centuries, and by preserving and correctly promoting its heritage it can maintain this status in the future (cf. Marot in Harfst 2012). It can attract visitors (e.g., tourists, researchers, future investors, and students) by forming and marketing a comprehensive range of services in tourism, technology, cuisine, and the arts. In this regard, it is important that visitors feel welcome; to begin with, by providing sufficient accommodation capacities, basic services, and opportunities to set up educational and artistic camps, and business and research conferences.

The key goal of revitalization is to develop an effective economy and attract new investors. From the viewpoint of the economy, Idrija is dealing with specific circumstances. Two activities have predominated in this area: first there was the former mercury mine and, after it was closed down, the local economy was successfully restructured to the electrical industry. Both activities have stabilized the socioeconomic situation of residents and reflect the innovative orientation of this area; however, the stable social situation

Figure 4: Logging sluices are also part of world heritage. The photo shows the Brus sluice (also known as the Belca sluice).

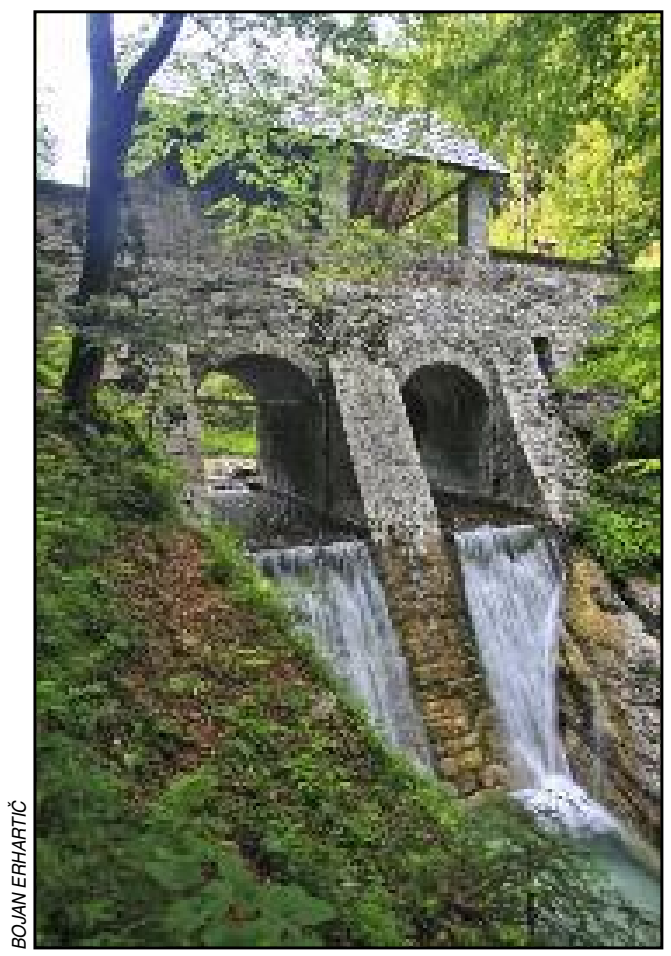


in particular was said to reduce local entrepreneurial initiatives (Nared et al. 2011). From this perspective, the establishment of new companies in the service sector will have to be encouraged in Idrija. One incentive that can be offered by the municipality would be allowing cost-effective rentals of unused municipal real estate, which would directly promote the development of an entrepreneurial incubator in the city center.

A direct measure to revive Idrija is also promoting mixed use of land and buildings that can benefit all users: residents, entrepreneurs, and visitors. The key element in this regard is establishing effective urban transport with at least partial removal of parking from the most attractive locations in the city. The city center has open and closed urban spaces of sufficient quality that could attract people and encourage them to socialize and work together, but in some cases they need (additional) infrastructure, which can be provided by connecting various suppliers and providers. Forming connections between the city residents and institutions directly in charge of preserving and promoting heritage in Idrija (e.g., during the lace-making festival) would be an important addition to the generally effective systems for protecting individual heritage segments. These types of connections strengthen interpersonal solidarity and support. Thanks to mining, both have already been present in Idrija for centuries. Therefore, it must be ensured that they do not die out despite the closing down of the mine, and instead materialize in alternative forms such as intergenerational cooperation and the transfer of an extensive body of knowledge from old to young people.

\section{Conclusion}

Today cultural heritage is a value that is generally formally protected by a series of international, nation$\mathrm{al}$, and local regulations, conventions, laws, and decrees, but in reality it only possesses the value that the user ascribes to it (Fister 2003). In the case of Idrija, this is first and foremost its people, and therefore the protection of cultural heritage must simultaneously ensure the development of a high-quality living environment in addition to preserving its symbolic and technical heritage. In this regard, it should be noted that inclusion on the UNESCO list does not entail new protection regimes; the starting point is always the national regulations. UNESCO merely enhances their importance and promotes their consistent monitoring. Thus, with its inclusion on the UNESCO list, Idrija is gaining numerous opportunities: a more comprehensive approach to protecting and using cultural heritage, positioning on the world map of tourist destinations with a rich cultural and technical heritage, development of tourism and related activities (catering, hotels, and souvenir production and sales), and enhanced regional awareness. However, all of this also demands consistent protection of cultural heritage, and thus its integrity and authenticity, because this is the only way to achieve sustainable solutions that are successful in the long term. This is therefore the primary task of a management plan.

\section{Acknowledgement}

This article was prepared as part of the CHERPLAN (Enhancement of Cultural Heritage through Environmental Planning and Management) project co-financed by the European Regional Development Fund, and the program Geography of Slovenia co-financed by the Slovenian Research Agency.

\section{References}

Athens Charter for the Restoration of Historic Monuments. 1931. Internet: http://www.icomos.org/en/charters-and-texts/179-articles-en-francais/ressources/charters-and-standards/167-the-athens-charter-forthe-restoration-of-historic-monuments (12.12.2012).

Blešić, I., Pivac, T., Stamenković, I., Đorđević, J., Janićević, S. 2013: Local Population Attitudes on Cultural Events in Sombor and Apatin Municipality Areas. Acta Geographica Slovenica 54-21. Ljubljana. DOI: 10.3986/AGS54406

Charter on the Principles for the Analysis, Conservation, and Structural Restoration of Architectural Heritage. 2003. Internet: http://www.international.icomos.org/charters/structures_e.pdf (13.12.2012). 
Convention Concerning the Protection of the World Cultural and Natural Heritage. 1972. United Nations Educational, Scientific and Cultural Organization. Paris.

Convention for the Safeguarding of Intangible Cultural Heritage. 2003. Internet: http://www.unesco.org/ culture/ich/index.php?lg=en\&pg=00022 (13.12.2012).

Doktrina 1: Mednarodne listine ICOMOS. 2003. Združenje za ohranjanje spomenikov in spomeniških območij ICOMOS/SI. Ljubljana.

Ferlež, A. 2007: Regionalna geografija mestnega jedra Celja in možnosti njegove revitalizacije. Bachelor's thesis, Filozofska fakulteta Univerze v Ljubljani. Ljubljana.

Fister, P. 2003: Varovanje kulturne dediščine kot nova vrednota. Doktrina 1. Mednarodne listine ICOMOS. Združenje za ohranjanje spomenikov in spomeniških območij ICOMOS/SI. Ljubljana.

Heritage of Mercury. Internet: http://www.idrija.si/images/datoteke/strateski_dokumenti/MERCURY\% 20HERITAGE\%20VOL\%20I\%20y\%20II.pdf (19.11.2012).

International Charter for the Conservation and Restoration of Monuments and Sites (Venice Charter). 1964. Internet: http://www.icomos.org/charters/venice_e.pdf (12.12.2012).

International Charter for the Conservation of Historic Towns and Urban Areas. 1987. Internet: http://www.international.icomos.org/charters/towns_e.pdf (12.12.2012).

International Charters for Conservation and Restoration. Internet: http://www.international.icomos.org/ charters/charters.pdf (13.12.2012).

Lapuh, V. 2012: Urbana prenova in predlog za revitalizacijo starega mestnega jedra Krškega. Bachelor's thesis, Fakulteta za gradbeništvo in geodezijo Univerze v Ljubljani. Ljubljana.

Marot, N., Harfst, J. 2012: Post-mining potentials and redevelopment of former mining regions in Central Europe - Case studies from Germany and Slovenia. Acta geographica Slovenica 51-2. Ljubljana. DOI: $10.3986 /$ AGS52104.

Nared, J., Perko, D. (ed.) 2010: Na prelomnici: razvojna vprašanja Občine Idrija. Capacities 1. Ljubljana.

Nared, J., Smrekar, A., Bole, D., Kozina, J., Fridl, J., Polajnar Horvat, K., Gabrovec, M., Repolusk, P., Zavodnik Lamovšek, A., Sever, B. 2011: Inovativna strategija trajnostnega razvoja Občine Idrija. Research report, Geografski inštitut Antona Melika, Znanstvenoraziskovalni center Slovenske akademije znanosti in umetnosti. Ljubljana.

Operational Guidelines for the Implementation of the World Heritage Convention. 2012. United Nations Educational, Scientific and Cultural Organization. Paris.

Razpotnik Visković, N., Nared, J., Urbanc, M. 2008: Pogovor v kavarni: soočenje teorije in prakse. Geografski vestnik 80-1. Ljubljana.

Razpotnik Visković, N., Urbanc, M., Nared, J. 2009: Prostorska in razvojna vprašanja Alp. Georitem 12. Ljubljana.

Register nepremične kulturne dediščine. Internet: http://www.mizks.gov.si/si/storitve/kultura/razvidi_evidence_in_registri/register_nepremicne_kulturne_dediscine (6.12.2012).

Reurbanisation on the Condition of Demographic Change. Work Package 5 - Economics, Law and Governance, Final Report. 2005. Internet: http://www.re-urban.com/downloads/WP5_Final_Report_ver1.3-1.pdf (12.12.2012).

Ringbeck, B. 2008: Management Plans for World Heritage Sites. A Practical Guide. Bonn.

Straus, M., Alič, M., Carli, S., Javornik, M., Menart, Ž., Mikolič, P. 2011: Mladi občine Idrije. Stanje in želje. Idrija.

Šmid Hribar, M., Ledinek Lozej, Š. 2013: Vloga prepoznavanja in upravljanja kulturnih vrednot pri razvoju podeželja. Acta geographica Slovenica 53-1. Ljubljana. DOI: 10.3986/AGS53402

Urbanc, M., Nared, J., Bole, D. 2012. Idrija: A Local Player on the Global Market. Locality, Memory, Reconstruction: The Cultural Challenges and Possibilities of Former Single-Industry Communities. Newcastle upon Tyne.

Zumaglini, M., Nared, J., Alfarè, L., Razpotnik, N., Urbanc, M. 2008: Participation Process in Regional Development: DIAMONT's Perspective. Arbaitshefte/Quaderni 52. Bolzano/Bozen. 